\title{
Autour de 1914. Nouvelles figures de la pensée :
} sciences, arts, lettres

Colloque de rentrée. 16 et 17 octobre 2014

URL : https://journals.openedition.org/lettre-cdf/4698

DOI : $10.4000 /$ lettre-cdf.4698

ISSN : 2109-9219

\section{Éditeur}

Collège de France

Édition imprimée

Date de publication : 1 mars 2015

Pagination : 11

ISSN : 1628-2329

Référence électronique

"Autour de 1914. Nouvelles figures de la pensée : sciences, arts, lettres », La lettre du Collège de France [En ligne], 39 | mars 2015, mis en ligne le 26 novembre 2015, consulté le 17 août 2022. URL : http:// journals.openedition.org/lettre-cdf/4698 ; DOI : https://doi.org/10.4000/lettre-cdf.4698 
